KockovÁ-Kratochvílová, A. \& Svobodová-PolÁková, Y. (1959). J. gen.Microbiol. 20, 24-26

\title{
Nadsonia slovaca n.sp. Isolated in Slovakia
}

\author{
BY ANNA KOCKOVA-KRATOCHVÍLOVA AND \\ YVONNE SVOBODOVÁ-POLAKKOVÁ \\ Department of Technical Microbiology and Biochemistry of the Chemical Faculty \\ of the Technical University of Bratislava, Czechoslovakia
}

SUMMARY: In the region of the mountains of Malé Karpaty and Harmanec in Slovakia a new species, Nadsonia slovaca, was isolated. The species was found on the surface of the fruits of Cornus mas, on the surface of the fruiting bodies of Amanita muscaria, Nematoloma lateritium and $N$. fasciculare and in the water of the brook Bystrica. The new species differed from those described hitherto by the formation of abundant pseudomycelium on the margin of slimy streaks and by the formation of big, bag-like, granulated cells. The new species did not ferment any sugars.

In 1957 we studied the natural yeast microflora in the region of Malé Karpaty and in the water of the brook Bystrica in the neighbourhood of Harmanec. We isolated several strains of the genus Nadsonia. The isolation was accompanied with considerable difficulties as all these strains were contaminated by bacteria which resisted the acidic nature of Raulin's solution. We succeeded in isolating six strains: MK39 from the surface of the fruits of Cornus mas, growing in a hedge of vineyard on the slopes of the Malé Karpaty mountains near Modra; MK15 from the surface of Amanita muscaria, growing in a pine forest in the vicinity of a deserted stone quarry, MK 42 from the surface of Nematoloma lateritium growing in a mixed oak-beech forest along the road from Červený Kameň to a locality called Karlubek in the mountains of Malé Karpaty; MK 43 from the surface of $N$. fasciculare growing in a mixed oakbeech forest in a locality called Karlubek, which is north-west of the castle of Červený Kameň. Strains H11 (H1 V) and H12 (H2V) were isolated from the water of the brook Bystrica, the water of which was contaminated by waste water from a paper factory. The brook Bystrica was divided into five profiles of different intensity of pollution and both strains were isolated from the profile no. 4 belonging to the polysaprobic biological region with a tendency to alfa-mesosaproby. The temperature of the water of the brook Bystrica at the time of sampling was $14.5^{\circ}$. The strains were isolated from water and from natural sources in August and September, respectively.

\section{METHODS AND RESULTS}

Growth in malt extract after 3 days at $25^{\circ}$. Pellicles were formed on the surface of the broth by all the cultures.

Dimensions of cells. See Table 1.

Growth on malt agar at $25^{\circ}$ after 3 days. The brownish ivory-coloured growth was slimy, glistening and high; it formed abundant pseudomycelium on the 
margin. Upon prolonged cultivation on wort agar the slimy character diminished and acquired a fatty glistening and wrinkled appearance with a still more abundant growth of pseudomycelium.

Slide cultures on potato agar at $25^{\circ}$. A distinct pseudomycelium was formed on the margin of the colonies after 5 days of cultivation (Pl. 1, fig. 1). The pseudomycelium formed by cells of similar morphological character was irregularly branched.

Table 1. Dimensions of cells of the six strains of Nadsonia slovaca, n.sp.

\begin{tabular}{|c|c|c|c|c|c|c|c|}
\hline \multirow{2}{*}{$\begin{array}{c}\text { Strain } \\
\text { no. }\end{array}$} & \multirow{2}{*}{$\begin{array}{c}\text { Size } \\
\text { variances } \\
(\mu)\end{array}$} & \multicolumn{2}{|c|}{ Mean length $(\mu)$} & \multicolumn{2}{|c|}{ Mean width $(\mu)$} & \multirow{2}{*}{$\begin{array}{c}r \\
\text { coefficient } \\
\text { of } \\
\text { correlation }\end{array}$} & \multirow{2}{*}{$\begin{array}{c}l: w \\
\text { ratio of } \\
\text { length } \\
\text { and } \\
\text { width }\end{array}$} \\
\hline & & $\bar{x}$ & $s \bar{x}$ & $\bar{y}$ & $s \bar{y}$ & & \\
\hline MK 15 & $(4-12) \times(2-5)$ & $6 \cdot 46$ & $0 \cdot 192$ & $2 \cdot 86$ & 0.083 & $0 \cdot 16$ & $2 \cdot 25$ \\
\hline MK39 & $(2-9) \times(2-8)$ & $7 \cdot 46$ & $0 \cdot 183$ & $3 \cdot 98$ & $0 \cdot 092$ & $0 \cdot 27$ & $1 \cdot 87$ \\
\hline MK42 & $(2-9) \times(2-8)$ & $7 \cdot 01$ & $0 \cdot 164$ & $3 \cdot 77$ & $0 \cdot 086$ & $0 \cdot 41$ & $1 \cdot 85$ \\
\hline MK43 & $(3-16) \times(2-5)$ & $6 \cdot 98$ & $0 \cdot 217$ & $3 \cdot 45$ & 0.073 & $0 \cdot 46$ & 2.02 \\
\hline H1 V & $(3-6) \times(4-10)$ & $6 \cdot 72$ & $0 \cdot 107$ & $4 \cdot 24$ & $0 \cdot 021$ & 0.45 & 1.57 \\
\hline $\mathrm{H} 2 \mathrm{~V}$ & $(3-16) \times(4-10)$ & $8 \cdot 15$ & $0 \cdot 173$ & $5 \cdot 02$ & 0.068 & 0.51 & $1 \cdot 62$ \\
\hline
\end{tabular}

Sporulation. The spores of all six strains were observed in a phase contrast microscope. The sporulation of our strains was similar to the sporulation of the genus Nadsonia, described in the literature (Lodder \& Kreger-van Rij, 1952). The spores appeared big, spherical, white with a bright brownish-red centre. Before sporulation large, bag-like cells with granules possessing high refractive power were observed (Pl. 1, fig. 2). We consider the bag-like cells to be in a presporulative state, which was observed by us also with other sporulating yeasts (Kocková-Kratochvílová, Kutková \& Petrová, 1957). Usually one spore was seen in every ascus.

Assimilation of individual sugars. All six strains assimilated glucose, galactose, maltose, sucrose, lactose and arabinose.

Assimilation of sugars from a solution containing different sugars. (KockováKratochvílová \& Vojtková-Lepšíková, 1958). From a solution containing different sugars all six strains assimilated arabinose and galactose prior to the assimilation of maltose.

Optimal cultivation temperature. $18-20^{\circ}$.

Fermentation of sugars. Absent.

Assimilation of potassium nitrate. Positive.

Assimilation of ethanol. Ethanol was assimilated extremely well by all six strains, which formed a thick pellicle on the surface of the medium.

\section{DISCUSSION}

Our description was made according to the procedure of Lodder \& Kreger-van Rij (1952) and according to Kudriavtshev (1954). As Lodder \& Kreger-van Rij did not describe any pseudomycelium-forming species of the genus Nadsonia we originally presumed our strains to be similar to the genus Nadsoniomyces Kudriavtshev. We tried to compare the bag-like granulated cells of our strains 
with the cells of Nadsoniomyces, which are pointed at one end. The granules of our bag-like cells possess no filaments nor did we observe any formation of arthrospores, both of which are described by Kudriavtshev. As our strains resemble the genus Nadsonia Sydow, we have decided to include our strains in this genus. Our strains differed only by the formation of abundant pseudomycelium and by the absence of fermentation of sugars. We consider our strains to be a new species, which we name Nadsonia slovaca. It has been deposited in the Centraalbureau voor Schimmelcultures, Baarn, Holland.

Latin diagnosis. Nadsonia slovaca sp.n.

In musto maltato cellulae oblongae, rhomboidae, praeacutae, $(2-16) \times(2-10) \mu$, singulae. Post dies 3 pellicula crispulata, flavalbida, atque sedimentum formantur.

In agare maltato cellulae formae et dimensiones, cellularum eadem sunt, qua in musto maltato. Cultura post dies 15 flavalbida, glabra et mucilaginosa, margine piloso. Pseudomycelium abundant. Cellulae pseudomycelii oblongae in catenis ramosis.

Ascosporae rotundae, magnae, albae cum centro rubrobruneo. Sporulatio talis, qualis apud genem Nadsonia describitur.

Fermentatio nulla. In medio minerali cum glucoso, maltoso, saccharo, lactoso, arabinoso crescit. Nitras Kalii assimilatur. In medio minerali cum alcohole aethylico crescit, magna pellicula formatur.

\section{REFERENCES}

Kocková-Kratochvílová, A., Kutková, M. \& Petrová, M. (1957). Zur Frage des Erregers der interstitiellen plasmazellulären Pneumonie bei Säuglingen. Naturwissenschaften, 44, 565.

Kocková-Kratochvflová, A. \& VoJtková-Lepšínova, A. (1958). Eine neue Art der Beurteilung der Assimilationsfähigkeit der Hefe. Naturwissenschaften, 45, 773.

Kudriavtshev, V. I. (1954). Sistematika drozhej. Moskva: Izdatelstvo Akademii Nauk SSSR.

Lodder, J. \& Kreger-van RiJ, N. J. W. (1952). The Yeasts. Amsterdam: North Holland Publishing Company.

\section{EXPLANATION OF PLATE}

Fig. 1. Marginal mycelium on a slide culture on potato agar.

Fig. 2. Cells of Nadsonia slovaca n.sp., bag-like cells and germinating spores. $\times 1000$.

(Received 16 June 1958) 
Journal of General Microbiology, Vol. 20, No. 1

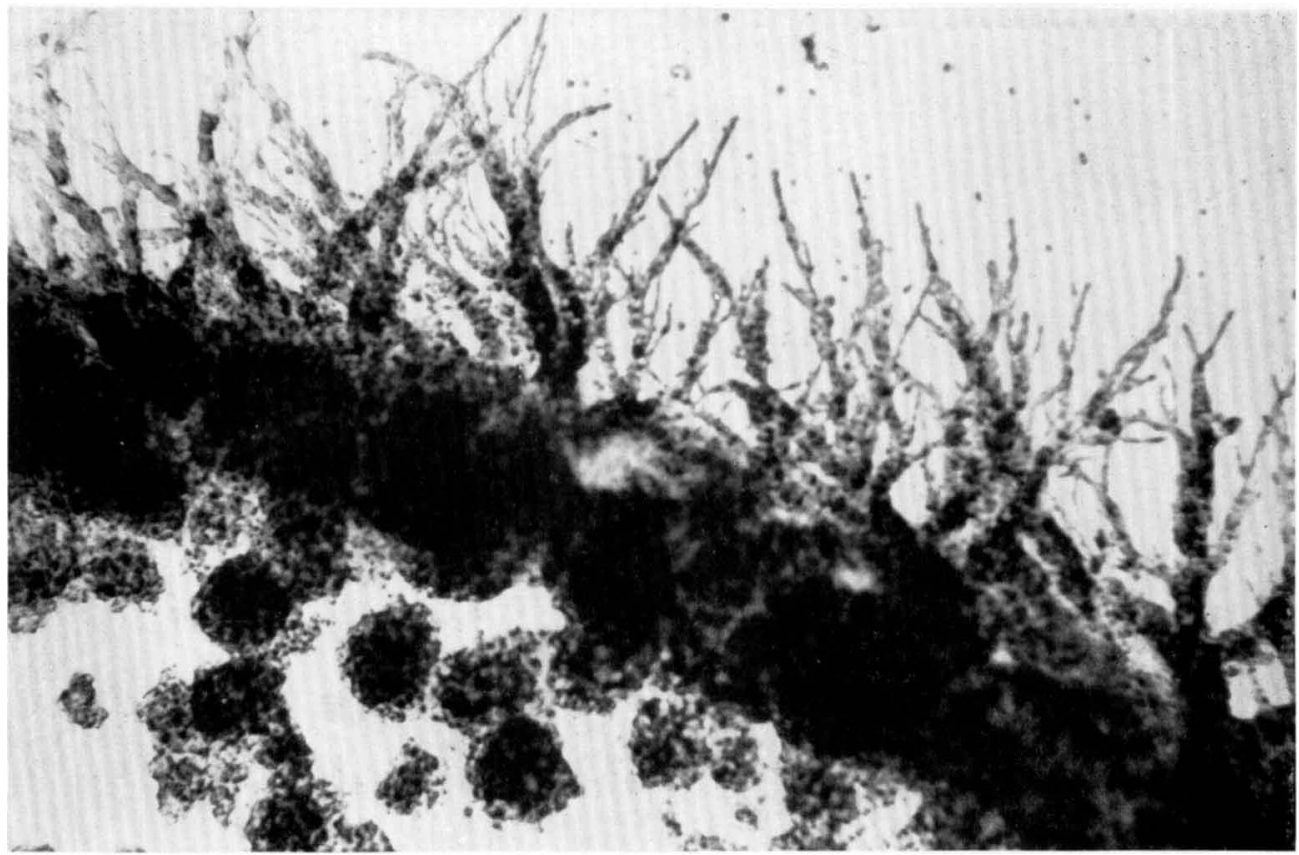

Fig. 1

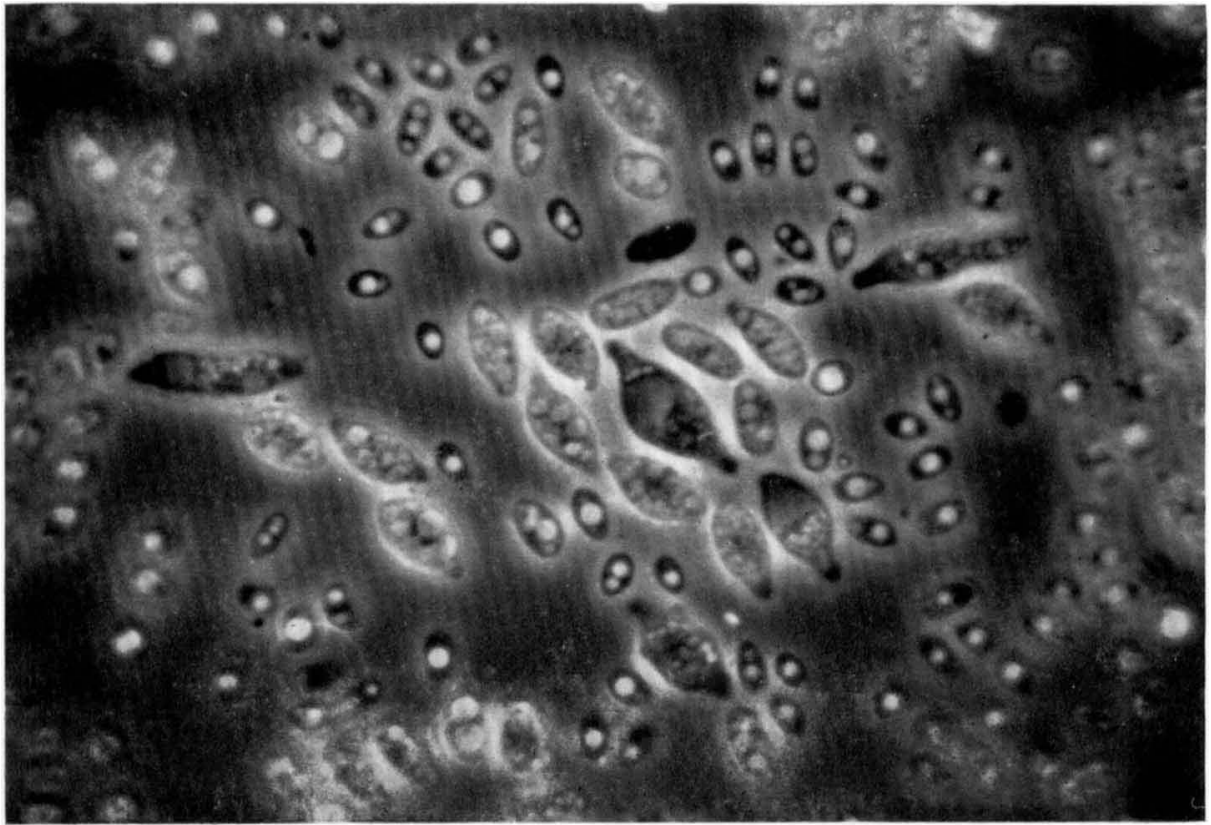

Fig. 2

A. Kocková-Kratochvílová \& Y. Svobodoví-Poláková-Nadsonia SLOVACA N.SP. Pla'te 1 